\title{
IgE Glycosylation in Health and Disease
}

\author{
Kai-Ting Shade, Michelle E. Conroy, Robert M. Anthony \\ Center for Immunology and Inflammatory Diseases, Massachusetts General Hospital, Harvard \\ Medical School, Boston, MA 02129, USA
}

\begin{abstract}
IgE are absolutely required for initiation of allergy reactions, which affect over $20 \%$ of the world's population. IgE are the least prevalent immunoglobulins in circulation with 12-h and 2-day halflives in mouse and human serum, respectively, but an extended tissue half-life of 3-weeks bound to the surface of mast cells by the high affinity IgE receptor, FceRI (Gould and Sutton 2008). Although the importance of glycosylation to IgG biology is well established, less is known regarding the contribution of $\mathrm{IgE}$ glycosylation to allergic inflammation. IgE has seven and nine $\mathrm{N}$-linked glycosylation sites distributed across human and murine constant chains, respectively. Here we discuss studies that have analyzed IgE glycosylation and its function, and how $\operatorname{IgE}$ glycosylation contributions to health and disease.
\end{abstract}

\section{IgE Biology in Health and Disease}

IgE antibody induced inflammation is nearly synonymous with allergic disease, which affects one in five individuals worldwide. IgE are central to the mechanisms of immediate type hypersensitivity reactions. These antibodies are also somewhat enigmatic given that a comprehensive understanding of IgE biology has yet to be established. IgE antibodies are the subclass found least in the serum compared to $\operatorname{IgM}, \operatorname{IgG}$ and $\operatorname{IgA}$, with a concentration of $50-100 \mathrm{ng} / \mathrm{ml}$, markedly lower than $\mathrm{IgG}(5-10 \mathrm{mg} / \mathrm{ml})$. Compared to its long tissue half life of weeks, IgE serum half life is only 2-3 days (Vieira and Rajewsky 1988). Structurally, it differs from IgG in that it contains four domains in the constant region (Ce1-4, Fig. 1a) compared to three in $\operatorname{IgG}$ (Gould et al. 2003). In the constant domains, receptor binding occurs, yielding IgE effector functions. The IgE receptor, FceRI, has strikingly high affinity for the antibody, $\sim 10^{11} \mathrm{M}^{-1}$, and is the source of the long tissue phase of IgE (Chang 2000). FceRI coats the surface of cells including mast cells, basophils, as well as dendritic cells, Langerhans cells and eosinophils in humans. Notably, there are structural variations in FceRI present in these cell types which result in differential effects upon binding. Mast cells and basophils express FceRI as a tetramer, $\alpha \beta \gamma_{2}$, with the $a$ unit responsible for $\operatorname{IgE}$ binding at the Ce3 domain. The $\beta$ chain of the receptor is mainly responsible for signal amplification and is notably absent in the trimeric form of FceRI, $a \gamma_{2}$ present on dendritic cells, Langerhan cells, and eosniphils. The $\gamma$ subunit is critical as it is the main structure responsible for orchestrating intra-cellular signaling pathways (Kraft and Kinet 2007). Allergen binding to IgE and subsequent cross linking of FceRI receptors activates ITAMs 
and subsequent downstream signaling. Specifically, FceRI is responsible for the canonical symptoms of immediate type hypersensitivity reactions detailed below.

There is a second IgE receptor, known as both CD23 and FceRII. This is often referred to as the "low affinity" receptor given that the affinity coefficient, $10^{6}-10^{7} \mathrm{M}^{-1}$, is dwarfed by that of FceRI. This immunoglobulin receptor has a trimeric C-type lectin like globular domains extracellularly, one transmembrane domain and a short cytoplasmic domain. Interestingly, CD23 can be either membrane bound or soluble forms. CD23 is expressed across a variety of cells including $\mathrm{T}$ and $\mathrm{B}$ lymphocytes, follicular dendritic cells, and epithelial cells (Armitage et al. 1989; Rieber 1993; Yu et al. 2003). Upon activation, membrane bound CD23 causes suppression of IgE production by B cells. Secreted CD23 can exist in monomeric or trimeric structures and can either down or up-regulate IgE synthesis, depending of its oligomerization (McCloskey et al. 2007). Taken together, CD23 is a potent factor in maintaining IgE homeostasis. Additional cells including antigenpresenting and gut epithelial cells utilize CD23 for transcytosis cross epithelial barriers and subsequent allergen presentation to the immune system (Palaniyandi et al. 2011).

As mentioned above, IgE antibodies are present in very low levels in the serum, particularly compared to other immunoglobulin subclasses. This suggests that control of IgE production is very tightly regulated. After initial and successful VDJ recombination yields a functional B cell receptor, production of eventually IgE occurs as a result of IgM+ and IgD+ B cell activation. Tissue Th2 cells as well as Tfh and Th2-like cells in lymphoid organs have been identified as possible sources of cytokines to promote B cell preferential class switch to IgE (Reinhardt et al. 2009). Class switch recombination (CSR) to IgE is triggered upon ligation of CD40, certain toll like receptors or BAFF in the context of IL4 exposure (Geha et al. 2003). Transcription promoters lie just upstream of DNA switch (S) regions and are responsible for "selection" of particular S recombinations and resultant specific antibody subclass production. In the case of IgE, ligation of the IL-4 receptor triggers STAT6 activation which is phosphorylated and translocates to the nucleus, binding the IgE promoter (Hebenstreit et al. 2006). For counter-regulation, Bcl-6 can bind sites in the IgE promoter which overlap with STAT6 binding loci, leading to inhibition of IgE class switch (Harris 1999). Notably, class switch to IgE can occur in two possible ways- direct switch from IgM to $\operatorname{IgE}$ or IgM to IgG and finally IgE. In B cells stimulated by IL4 and LPS, IgG1 was produced initially and IgE several hours later (Mandler 1993). Wesemann et al. then showed similar sequential production in the context of IL4 and anti-CD40 stimulation (Wesemann et al. 2011). Preferential class switch between $\operatorname{IgG}$ and $\operatorname{IgE}$ is determined by various factors. Intriguingly, the IgG1 switch region contains the most target sequences for AID, the enzyme responsible for class switching, and $\operatorname{IgE}$ the fewest. The IgG1 switch region may also block accessibility to the IgE S region (Misaghi et al. 2013) and accessibility to the IgE S region also seems to occur with a delayed rate (Wesemann et al. 2012). Taken together, control of class switching to IgE is an important means through which the antibody level can be tightly controlled. In addition, and critically, sequential class switch to IgE results in high-affinity antibody, perhaps owing to the longer timeline and persistent exposure to AID, also responsible for affinity maturation. Direct class switch from IgM directly to IgE results in lower affinity antibodies (He et al. 2015). This has significant functional repercussions. 
When considering where and when IgE class switch recombination, production and memory occur there are some puzzling curiosities. First and foremost, there seems to be an overall lack of IgE memory B cells found in immunologic tissues (Yang, Sullivan, and Allen 2012). Typically, in lymphoid germinal centers (GCs), B cell proliferation occurs with concurrent affinity maturation and positive selection via interactions with follicular dendritic cells and Tfh cells. Therefore, GC interactions are critical for the eventual development of memory B cells and plasma cells resulting in long lived antibody memory (Janeway et al. 2001). Murine studies demonstrated while IgE+ B cells were not found in spleen or lymph nodes, plasma cells represented the preponderance of IgE producing cells in these animals. These cells were noted to have undergone sequential switching, with an IgG intermediate, followed by rapid differentiation to IgE expressing plasma cells (Erazo et al. 2007). He et al. were able to show that $\mathrm{GC} \mathrm{IgE}^{+}$cells do exist but that they expressed significantly lower expression of surface antibody, weak BCR signaling and did not populate GC light zone. This suggested that $\operatorname{IgE}^{+}$cells in germinal centers were dying prematurely in the maturation process (He et al. 2013). As noted previously, sequential class switching from $\operatorname{IgG}$ to $\operatorname{IgE}$ seems to provide the most significant source of high affinity antibody. Thus, $\mathrm{IgG}^{+} \mathrm{B}$ cells have been hypothesized as the source of IgE memory. B220 ${ }^{+} \mathrm{CD} 138^{-} \mathrm{IgG} 1^{+} \mathrm{B}$ cells have been identified as the cell population responsible for significant IgE memory production ( $\mathrm{He}$ et al. 2013). Further, the same group identified a murine IgG1 memory B cell subset which was able to generate $\mathrm{IgE}^{+}$plasma cells and produce high affinity, functional antibody, able to trigger anaphylaxis in a murine model (He et al. 2017). Therefore, $\operatorname{IgG}+\mathrm{B}$ cells serve as a main reservoir for $\mathrm{IgE}$ memory along with $\mathrm{IgE}^{+}$plasma cells. It is notable that direct class switch from IgM to IgE results in low affinity antibody production and short lived $\mathrm{GC} \operatorname{IgE}^{+}$ cells. Together, these cells and mechanisms are the source of both high and low affinity $\operatorname{IgE}$ antibodies and maintain the functional pool of $\operatorname{IgE}$ (He et al. 2015).

IgE antibodies have gained significant attention as the incidence of allergic diseases has increased substantially. The World Allergy Organization estimates that a staggering 30-40\% of the world's population suffers from one or more allergic conditions (Pawankar et al. 2011). This contributes to substantial burden of illness and the economic implications are massive, thought to cost billions of dollars in medical visits and lost productivity (2010). Atopic diseases are considered to be one of the principle manifestations of IgE driven pathology. As discussed above, allergen specific IgE antibodies are bound to the surface of mast cells and basophils via Fc binding to the FceRI receptor. Allergen cross linking of cell bound IgE results in cellular degranulation and canonical symptoms of allergic inflammation. Immediate release of mediators causes rapid onset of vascular dilation and permeability, bronchoconstriction, leukocyte extravasation and smooth muscle contraction. Cellular activation also results in synthetic processes which generate mediators of "late phase" reactions (Holgate 1982). These processes result in clinical symptoms including potentially fatal anaphylaxis. Allergen specific IgE can be utilized for diagnostics in allergy and is a target of therapies in asthma, environmental/food/venom allergies and atopic dermatitis.

Yet, significant IgE biology extends beyond allergic inflammation and atopic diseases. It has been implicated in protection against parasitic infection and venom exposures. Additionally, several non-allergic diseases also have IgE implicated in their pathogenesis. As previously 
described, IgE antibodies coat the surface of mast cells via the FceRI receptor. Mast cells localize to vascularized tissues and are especially concentrated at mucosal and skin surfaces (Gurish and Austen 2012). In the context of parasitic infections, both parasite specific and non-specific IgE antibodies markedly increase (Anthony et al. 2007). There is speculation that these increased IgE levels may trigger mast cell activation at mucosal surfaces leading to various biologic functions which ultimately lead to worm expulsion. In general, specific mechanisms responsible for these actions are not well elucidated (Fitzsimmons et al. 2014). In fact, in mice infected with Schistosoma mansoni, significant manipulations of IgE levels did not specifically modulate host pathology from infection, though may have contributed to liver pathology (Jankovic 1997). The specific biologic relevance of IgE with regard to parasitic immunity remains to be deciphered.

As they are in parasitic diseases, mast cells are also felt to confer innate protection against toxic proteins such as those from insects and snakes. In murine models, venom proteins administered in vivo trigger mast cells to release pre-formed heparin that contribute to toxin neutralization (Mukai et al. 2016). Mast cell proteases have also been shown to directly reduce toxicity of venoms (Metz et al. 2006). Specific IgE antibodies against insect venoms are used as diagnostic tools to identify persons allergic to these proteins who may be at risk of anaphylaxis with subsequent exposures. It has therefore been presumed that anti-venom $\mathrm{IgE}$ antibodies are pathogenic. However, with consideration of mast cell protective functions in the context of toxin exposures, several groups have questioned whether venom specific IgE may play a role in facilitating mast cell protective responses. Mice immunized with whole bee venom generated both $\operatorname{IgG} 1$ and $\operatorname{IgE}$ venom specific antibodies. Immunized mice were more resistant to subsequent exposure to lethal dosing of the same venom. $\operatorname{IgE}$ deficient and $\mathrm{FceRF}^{-/-}$mice did not demonstrate this same resistance. Passive immunization with bee venom antibody containing serum also provided protection upon bee venom administration in IgE deficient mice (Marichal et al. 2013). In mice who were administered repeated immunization with phospholipase $\mathrm{A} 2$, known to be a potent allergenic component of honeybee venom, protection was established against subsequent lethal honeybee venom. This protection did not occur in mice who were B cell deficient or in those with dysfunctional FceRI (Palm et al. 2013). Given that most humans with venom specific IgE have never had anaphylaxis in the context of exposure, Mukai et al. speculate that improved protection against venomous exposures may be an "ancient and fundamental" function of IgE and mast cells (Mukai et al. 2016).

IgE has largely been implicated in allergic diseases. However, their presence in diseases primarily involving immune system dysregulation have raised questions as to a more global immunologic role for IgE antibodies. As an example, decades ago, self-reactive $\operatorname{IgE}$ antibodies and IgE containing immune complexes were found in patients with systemic lupus erythematosus (SLE) (Miyawaki S 1973). It has been well established that self reactive immune complexes lead to production of type I interferons by plasmacytoid dendritic cells in SLE (Ronnblom 2001). Recently, Henault et al. demonstrated that the presence of DNA-IgE autoantibodies in human SLE caused self-DNA triggered TLR9 activation in plasmacytoid dendritic cells facilitated by the interaction of IgE/FceRI. This lead to markedly increased production of IFN-a (Henault et al. 2016). They speculate that self dsDNA-IgE complexes may contribute to increased loss of tolerance and exacerbation 
of pathology as a result. In fact, higher levels of self-reactive dsDNA-IgE in the serum correlated with disease severity.

Immune deficiencies provide another clinical example in which IgE is elevated in the context of immune dysregulation. Hyper-IgE (HIES) or Job syndrome is a complex disease in which IgE levels can reach levels of more than 20,000 IU/L, orders of magnitude higher than normal (Sowerwine et al. 2012). The disease presents with a mysterious combination of symptoms including Staph aureus abscesses, eczematous rashes, recurrent sinopulmonary infections, chronic candida infections, eosinophilia, fungal infections, and EBV and VZV infections (Siegel et al. 2011). Notably, patients with HIES also present with osseous abnormalities including craniofacial dysmorphology, delayed tooth eruption and high arched palate (Nieminen et al. 2011). Malignancy affects significant numbers of these people as well, involving both blood and solid organs. These clinical manifestations are the result of STAT3 mutations on chromosome 17. This leads to abnormalities in the IL-6 pathway (Holland et al. 2007) and, significantly, marked inhibition of the Th17 immunologic response (Milner et al. 2008). The specific mechanisms responsible for the marked elevation in IgE levels is not fully known. Interestingly, Liu et al. recently showed that STAT3 deletion in keratinocytes of mice with eczema-like inflammation surprisingly lead to a marked elevation in IgE levels (Liu 2017). Cutaneous inflammation in this model was induced by $S$. aureus, which is also responsible for significant disease pathology in patients with HIES. Other immune deficiencies including DOCK8 deficiency, TYK2 deficiency, Omenn's syndrome, Wisoctt-Aldrich syndrome, DiGeorge syndrome, Netherton and IPEX syndromes have elevated IgE as a hallmark (Mogensen 2016). Once again, how IgE occurs in and affects these conditions is poorly understood and studies are ongoing to improve understanding.

\section{$2 \lg$ E Structure}

$\operatorname{IgE}$ and $\operatorname{IgG}$ are perhaps the most clinically relevant immunoglobulin classes. Further, there are a number of superficial similarities shared between these two molecules. Both are monomeric immunoglobulins comprised of two identical heavy chains and two identical light chains, and exert their canonical effector functions through interactions with $\mathrm{Fc}$ receptors expressed by innate cells. IgE heavy chains have four constant domains, and a single variable domain, and light chain has single constant and variable domains. Both IgE and $\mathrm{IgG}$ have been shown to adopt open and closed structures, that result in different $\mathrm{Fc}$ receptor binding profiles. While a single $\mathrm{N}$-linked glycosylation site is present in all $\mathrm{IgG}$, $\mathrm{IgE}$ is the most heavily glycosylated monomeric antibody.

Seven N-linked glycosylation sites are distributed across the constant domains of the human IgE heavy chains, while 9 sites are found on mouse IgE (Fig. 1a). One site, at asparagine (N) 394 on human IgE, is conserved across all mammalian IgE. The glycan that occupies the conserved site has an oligomannose structure (Fig. 1a, b). Indeed, this site is reported to be orthologous to the IgG glycosylation site (Wurzburg et al. 2000). Indeed, crystal structure of $\operatorname{IgE}$ and $\operatorname{IgG}$ Fcs feature a glycan, which is consist with glycans having a fixed position in the molecule. On human IgE, the remaining sites barring N383, which is unoccupied, contain mono- and di-sialylated complex biantennary glycans. Indeed, the published data on 
$\mathrm{IgE}$ from allergic patients is currently lacking, as analysis are restricted to $\mathrm{IgE}$ from serum of non-atopic (Plomp et al. 2013), hyperimmune (Arnold et al. 2004; Plomp et al. 2013), IgE myeloma (Plomp et al. 2013), and hyper IgE (Wu et al. 2016) patients, and recombinant sources (Shade et al. 2015). The IgE molecule adopts a bent horseshoe structure, where the Fab and Fc domains are folded towards each other. Further, the IgE Fab is rigid, unlike the flexible IgG hinge. It is thought the IgE molecule can rotate around it central axis reciprocally refolding. To date, no studies have detected the presence of O-linked glycosylation in IgE (Arnold et al. 2004; Plomp et al. 2013; Wu et al. 2016).

\section{IgE N394 Glycosylation Site and Oligomannose Glycan}

Important structural studies have revealed that $\operatorname{IgE}$ binds to FceRI at the $\mathrm{C} \varepsilon 3$ domains and CD23 at both $\mathrm{C} \varepsilon 3$ and $\mathrm{C} \varepsilon 4$ domains of the Fc (Garman et al. 2000; Holdom et al. 2011). The interaction to each receptor is dependent on $\operatorname{IgE}$ conformation and is mutually exclusive, with FceRI binding IgE in an open and CD23 in a closed conformation. The changes in conformation upon binding to one receptor disables binding to the other receptor. Over the past decade, strategies to alleviate IgE-mediated allergic diseases have generally been devised to prevent IgE-FceRI interaction. This includes an anti-IgE therapeutic antibody Omalizumab that binds to an epitope overlapping FceRI and directly prevents binding of serum free IgE to FceRI. Another engineered protein inhibitor, designed ankyrin repeat protein (DARPin E2_79) also binds to the $\mathrm{C} \varepsilon 3$ and accelerates the dissociation of $\operatorname{IgE}$ from FceRI on preformed complexes through an allosteric mechanism (Kim et al. 2012). Recently, a single-domain antibody derived from llama, sdab 026, have shown to inhibit IgE-FceRI interaction by locking IgE in a closed conformation similar to CD23 binding and prevents the open conformation that allows the FceRI interaction (Jabs et al. 2018).

Crystal structures of human IgE Fc also showed the glycans attached to N394 on the Ce3 domains occupy the cavity between two Fcs. This glycosylation site is evolutionary conserved across mammalian species and homologous to the key glycan attached on the IgG Fc (Jabs et al. 2018; Holdom et al. 2011; Wan et al. 2002; Garman et al. 2000; Sondermann et al. 2000). Previous studies have shown that $\mathrm{IgG} F \mathrm{~F}$ glycans are critical for maintaining antibody structural conformation. Removal of the Fc glycans results in a more closed conformation in the IgG Fcs and forfeits the functional conformation important for Fc $\gamma$ receptor binding (Krapp et al. 2003; Feige et al. 2009). In comparison, conflicting studies between 1980 and early 2000 that used aglycosylated IgE produced from Escherichia coli or deglycosylated IgE or IgE Fc after enzymatic treatments make it hard to determine whether glycosylation modulates IgE functions.

The earliest studies using E. coli-derived recombinant IgE Fc or Ce3 domains revealed that aglycosylated IgE binds to FceRI and can elicit IgE-mediated inflammation (Helm et al. 1998a, b; Henry et al. 2000). However, these proteins require additional manipulation including solubilization and refolding after recovery from bacterial insoluble inclusion bodies, which may compromise the native state of conformation. Later studies using enzymes to deglycosylate IgE Fc produced from mammalian cell lines or IgE derived from myeloma or serum showed incoherent results. While one study showed that deglycosylated IgE Fc retained binding to FceRI with minimal difference in a radioligand competition 
binding assay (Basu et al. 1993), another showed a 4-fold lower binding affinity to FceRI by SPR (Hunt et al. 2005). These results deviated from another study that showed significant impairment to FceRI binding upon enzymatic deglycosylation (Bjorklund et al. 1999, 2000). On the other hand, all studies that genetically disrupted the N-linked glycosylation site N394 on IgE or IgE Fc by mutating asparagine-394 to glutamine (N394Q) or threonine (N394T), or alternatively disrupting the site by substituting the third amino acid in the Asn-X-Ser/Thr sequon theronine-396 to alanine (T396A), all abolished FceRI binding and the subsequent IgE-mediated degranulation (Sayers et al. 1998; Shade et al. 2015; Jabs et al. 2018).

The functional significance of the glycan on $\operatorname{IgE~Fc}$ was further exemplified by the in vivo work using mouse models (Shade etal. 2015) The equivalent of N394 is N384 in mouse. In mouse, genetic mutation (N384Q or T386A) or enzymatic digestion of IgE by PNG to remove all $\mathrm{N}$-glycans lost the ability to bind FceRI in vivo in ear mast cells and in vitro in ELISA or cell-based binding assays. As expected, IgE lacking N384 glycans were also unable to initiate immediate anaphylaxis in a passive cutaneous anaphylaxis mouse model. In a reciprocal experiment where all $\mathrm{N}$-linked glycosylation sites were mutated except N384 (N384 only), this IgE was still able to elicit anaphylactic response similar to the WT, demonstrating that the glycan on the conserved site in IgE Fc is absolutely critical for IgE effector functions.

In contrast to the complex-type glycans on IgG Fc, all studies including crystal structure and glycopeptide mass spectrometry, uniformly identified the glycan attached to N394 is of oligomannose structures, with 2-9 mannose residues attached to two GlcNAc and $\mathrm{Man}_{5} \mathrm{GlcNAc}_{2}$ being the major form. IgE were sourced from monoclonal myeloma-derived, recombinant from different mammalian cell lines, serum of non-diseased donors, and serum of patients with hyperimmune conditions, IgE myeloma, atopic dermatitis or hyper IgE syndrome (Dorrington and Bennich 1978; Wan et al. 2002; Arnold et al. 2004; Holdom et al. 2011; Plomp et al. 2013; Shade et al. 2015; Wu et al. 2016). N-linked glycans of secreted mammalian proteins are typically processed to an intermediate oligomannose structure before further processed to hybrid and complex glycans in the lumen of the ER and the Golgi. As mentioned, all other N-linked sites of IgE are composed of complex glycans. Thus, it is unique for glycans at N394 to retain the oligomannose structures from being converted to complex type. The mouse IgE homologue also harbors oligomannose glycans at the conserved site.

The functional significance of glycans at N394 and its exclusive composition of oligomannose structures provide a unique therapeutic opportunity to target this glycan. Unlike some of the other glycosidases that cleave all types of N-linked glycans, Endoglycosidase F1 selectively hydrolyses the oligomannose and hybrid structures and leaves complex structures unaffected. Mirroring genetically disruption of N394 glycosylation site on IgE, EndoF1-treated recombinant or native allergic human IgE lost its ability to bind FceRI-expressed cells and elicit degranulation in mast cells. Mouse IgE digested with EndoF1 was also unable to initiate anaphylaxis in vivo (Shade et al. 2015). Being buried in the interstitial space between Fcs, the importance of N394 glycan is likely to maintain IgE protein structure as IgG glycans (Feige et al. 2009). Circular dichroism that measures the secondary structure of proteins revealed a shift in spectrum upon the loss of 
oligomannose glycans in $\operatorname{IgE}$ after EndoF1 treatment, reflecting changes in $\operatorname{IgE}$ threedimensional conformation (Shade et al. 2015). This change likely explains the loss of functional protein folding necessary to bind FceRI and initiate allergic inflammation.

In contrast to the requirement of IgE glycans in FceRI interaction, deglycosylated myeloma IgE was reported to augment binding to CD23 on B cells (Vercelli et al. 1989). This finding reinforces the idea that IgE conformation decides the exclusive interaction with FceRI or CD23. Perhaps the loss of glycans on IgE leads to a more closed conformation, thus promoting CD23 and preventing FceRI binding.

\section{Other N-Linked Glycosylation Sites on IgE}

IgE is one of the most heavily glycosylated antibody class. Besides N394, IgE has six other glycosylation sites, of which five are known to have complex glycans attached (Fig. 1a, b). While oligomannose glycans are composed of only GlcNAc and mannose residues, complex glycans have additional sugars including fucose that attaches to the core structure and galactose or sialic acid to the terminal. To date, studies that described complex glycans on human recombinant, myeloma-derived or native IgE all revealed fucosylated sialylated structures to be the major complex glycoforms (Dorrington and Bennich 1978; Arnold et al. 2004; Plomp et al. 2013; Shade et al. 2015; Wu et al. 2016). Previous study has reported that deglycosylated IgE has a propensity to form aggregate (Basu et al. 1993). Thus, glycans on $\mathrm{IgE}$ probably contribute significantly to the water solubility of $\mathrm{IgE}$ and removal of these hydrophilic, acidic glycans may increase exposure of hydrophobic regions and results in aggregation. Various studies that mutated glycosylation sites with complex glycans attached in IgE Fc have thus far suggested a minimal role in IgE- FceRI interaction. IgE/IgE Fc with single or double mutations at N265 and N374 sites was still able to bind FceRI with the same affinity as the WT and initiate degranulation (Nettleton and Kochan 1995; Young et al. 1995; Sayers et al. 1998; Shade et al. 2015). Interestingly, mutation of all N-linked sites in Cel domain of Fab portion showed a slight reduction in IgE-mediate degranulation (Shade et al. 2015), suggesting perhaps complex glycans in Ce1 modulates IgE interaction with the antigen.

Genetic disruption of the glycosylation site removes the entire glycan structure and disregards the roles that are dependent on the heterogeneity of the complex glycans. Studies of the complex glycans on IgG Fc demonstrated that these glycans are heterogeneous and can display more than 30 different glycoforms at a single site in healthy individuals (Kaneko et al. 2006; Wuhrer et al. 2007). These glycoforms reflect physiological processes and differ in diseases, serving as potential disease biomarkers. For example, changes in sialylation of $\mathrm{IgG}$ autoantibodies have been associated with clinical manifestation of the autoimmune and inflammatory diseases (Matsumoto et al. 2000; van de Geijn et al. 2009; Scherer et al. 2010; Ackerman et al. 2013a, b). Importantly, changes in glycoforms markedly modulate protein functions. When $\mathrm{IgG}$ is equipped with sialic acid, $\mathrm{IgG}$ shifts its receptor binding preferences and mediates anti-inflammatory activity (Kaneko et al. 2006; Anthony et al. 2008;

Sondermann et al. 2013; Pincetic et al. 2014). Further, IgG that lack fucose has enhanced antibody-dependent cellular cytotoxicity as a result of increased affinity to Fc $\gamma$ RIIIA by 50fold (Shields et al. 2002; Ferrara et al. 2011). 
In comparison to $\operatorname{IgG}$, the role of complex glycans in IgE is not known. Studies of the $\beta$ galactoside-binding lectins, galectins, have perhaps suggested the involvement of complex glycans in IgE-mediated functions. Galectin-3 has been shown to bind mouse IgE and activate IgE-sensitized rat basophilic leukemia cells (Frigeri et al. 1993; Liu et al. 1993; Zuberi et al. 1994). On the other hand, another galectin, galectin-9, has been shown to reduce mast cell degranulation and passive anaphylaxis by binding to IgE and inhibit its interaction with antigen (Niki et al. 2009). It is likely that these galectins bind to the complex glycans on the IgE to exert its regulatory roles. However, it is not clear how these two lectins work together in vivo, for example, whether they bind to the same glycans on $\mathrm{IgE}$ and their relevance in human physiology.

\section{Conclusions and Future Perspectives}

Despite its discovery over 50 years ago, much remains to be discovered relating to $\operatorname{IgE}$. As mentioned above, it is not clear precisely what makes allergen-specific IgE pathogenic in some individuals, and inert in other. However, their role in diseases of intense public health interest mandate ongoing pursuit of a comprehensive rendering of their function and regulation. $\operatorname{IgE}$ is the most heavily glycosylated monomeric antibody, and the conserved glycan at N394 has an important role in conformational folding and binding to FceRI. This work is in early stages and dedication to continued unraveling of the story is critical. However, even in these early stages of understanding, it is interesting to speculate as to how glycosylation could be a major factor in treatment of IgE-associated diseases in the future. As described previously, galectins may play a significant role in connecting IgE to its downstream effector functions. Recent studies have identified a role for Galectin-3 in the regulation of the IgE receptor, FceRI. Utilizing RNAi screening experiments, one group recently demonstrated Gal-3 as a negative regulator of FceRI triggered mast cell degranulation. Their data suggests Gal-3 may affect surface FceRI internalization, receptor mobility, F-actin polymerization, and FceRI ubiquination, all of which would profoundly impact mast cell signaling (Bambouskova et al. 2016). As altered variability in IgE glycosylation may impact galectin binding, it is certainly notable that activating or blocking interactions could yield substantial impact on the FceRI and mast cell function. This would have marked impact on allergic inflammation. As a notable clinical correlate, Galectin-3 has been increasingly identified as a biomarker in various allergic diseases. A recent study identified Gal-3 as a marker increased in eosinophilic asthma but notably decreased in neutrophilic asthma (Gao et al. 2015). This finding was extended by Riccio et al. demonstrating Gal-3 as a predictive marker for positive response to anti-IgE treatment of asthma. Subjects positive for Gal-3 at baseline had more improvement in bronchial wall thickening, eosinophilic inflammation, and smooth muscle involvement (Riccio et al. 2017). Beyond asthma, a specific Gal-3 polymorphism has recently been identified as a significant genetic predictor of allergy to beta-lactam antibiotics (Cornejo-Garcia et al. 2016). These examples provide early clinical evidence for what is an increasing connection between $\operatorname{IgE}$ antibodies, glycosylation, and co-receptors with biologic relevance.

With IgE glycosylation likely to be a significant factor in its biology and effector function, identification of relevant patterns associated with clinical disease will be critical. Once the specific glycan patterns associated with pathology are identified and the basic biology 
elucidated, novel diagnostic and therapeutic therapies can be extrapolated. Glycoengineering is an exciting future prospect where in vivo generation of antibody specific glycosylation could be utilized for reduction in inflammation. Indeed, modulation of $\operatorname{IgG}$ and tumor glycosylation has been reported by a number of groups, highlighting the therapeutic potential of these approaches (Albert et al. 2008; Xiao et al. 2016; Pagan et al. 2018). This may be one strategy of many to target IgE glycosylation for therapeutic benefit in the futures.

\section{Acknowledgements}

This work was supported by grants from the National Institutes of Health (DP2AR068272-01), and Food Allergy, Research, and Education (FARE) to RMA. We would like to apologize to all our colleagues whose important work was not cited here.

\section{References}

2010 Asthma's Impact on the Nation; Data from the CDC National Asthma Control Program. Center for Disease Control

Ackerman ME, Crispin M, Yu X, Baruah K, Boesch AW, Harvey DJ, Dugast AS, Heizen EL, Ercan A, Choi I, Streeck H, Nigrovic PA, Bailey-Kellogg C, Scanlan C, Alter G (2013a) Natural variation in Fc glycosylation of HIV-specific antibodies impacts antiviral activity. J Clin Invest 123(5):21832192. 10.1172/JCI65708 [PubMed: 23563315]

Ackerman ME, Dugast AS, McAndrew EG, Tsoukas S, Licht AF, Irvine DJ, Alter G (2013b) Enhanced phagocytic activity of HIV-specific antibodies correlates with natural production of immunoglobulins with skewed affinity for Fc $\gamma$ R2a and Fc $\gamma$ R2b. J Virol 87(10):5468-5476. 10.1128/JVI.03403-12 [PubMed: 23468489]

Albert H, Collin M, Dudziak D, Ravetch JV, Nimmeijahn F (2008) In vivo enzymatic modulation of IgG glycosylation inhibits autoimmune disease in an IgG subclass-dependent manner. Proc Natl Acad Sci U S A 105(39):15005-15009. 10.1073/pnas.0808248105 [PubMed: 18815375]

Anthony RM, Rutitzky LI, Urban JF Jr, Stadecker MJ, Gause WC (2007) Protective immune mechanisms in helminth infection. Nat Rev Immunol 7(12):975-987. 10.1038/nri2199 [PubMed: 18007680]

Anthony RM, Nimmerjahn F, Ashline DJ, Reinhold VN, Paulson JC, Ravetch JV (2008) Recapitulation of IVIG anti-inflammatory activity with a recombinant IgG Fc. Science 320 (5874): 373-376 [PubMed: 18420934]

Armitage RJ, Goff LK, Beverley PC (1989) Expression and functional role of CD23 on T cells. Eur J Immunol 19(1):31-35. 10.1002/eji.1830190106 [PubMed: 2522048]

Arnold JN, Radcliffe CM, Wormald MR, Royle L, Harvey DJ, Crispin M, Dwek RA, Sim RB, Rudd PM (2004) The glycosylation of human serum $\operatorname{IgD}$ and $\operatorname{IgE}$ and the accessibility of identified oligomannose structures for interaction with mannan-binding lectin. J Immunol 173 (11):68316840 [PubMed: 15557177]

Bambouskova M, Polakovicova I, Halova I, Goel G, Draberova L, Bugajev V, Doan A, Utekal P, Gardet A, Xavier RJ, Draber P (2016) New regulatory roles of Galectin-3 in high-affinity IgE receptor signaling. Mol Cell Biol 36(9):1366-1382. 10.1128/MCB.00064-16 [PubMed: 26929198]

Basu M, Hakimi J, Dharm E, Kondas JA, Tsien WH, Pilson RS, Lin P, Gilfillan A, Haring P, Braswell EH et al. (1993) Purification and characterization of human recombinant IgE-Fc fragments that bind to the human high affinity IgE receptor. J Biol Chem 268(18):13118-13127 [PubMed: 7685756]

Bjorklund JE, Karlsson T, Magnusson CG (1999) N-glycosylation influences epitope expression and receptor binding structures in human IgE. Mol Immunol 36(3):213-221 [PubMed: 10403487]

Bjorklund JE, Schmidt M, Magnusson CG (2000) Characterisation of recombinant human IgE-Fc fragments expressed in baculovirus-infected insect cells. Mol Immunol 37(3-4):169-177 [PubMed: 10865116] 
Chang TW (2000) The pharmacological basis of anti-IgE therapy. Nat Biotechnol 18(2):157-162. 10.1038/72601 [PubMed: 10657120]

Cornejo-Garcia JA, Romano A, Gueant-Rodriguez RM, Oussalah A, Blanca-Lopez N, Gaeta F, Tramoy D, Josse T, Dona I, Torres MJ, Canto G, Blanca M, Gueant JL (2016) A non-synonymous polymorphism in galectin-3 lectin domain is associated with allergic reactions to beta-lactam antibiotics. Pharmacogenomics J 16(1):79-82. 10.1038/tpj.2015.24 [PubMed: 25869013]

Dorrington KJ, Bennich HH (1978) Structure-function relationships in human immunoglobulin E. Immunol Rev 41:3-25 [PubMed: 100912]

Erazo A, Kutchukhidze N, Leung M, Christ AP, Urban JF Jr, Curotto de Lafaille MA, Lafaille JJ (2007) Unique maturation program of the IgE response in vivo. Immunity 26(2):191-203. 10.1016/j.immuni.2006.12.006 [PubMed: 17292640]

Feige MJ, Nath S, Catharino SR, Weinfurtner D, Steinbacher S, Buchner J (2009) Structure of the murine unglycosylated IgG1 Fc fragment. J Mol Biol 391(3):599-608. S0022-2836(09) 00768-2 [pii] 10.1016/j.jmb.2009.06.048 [PubMed: 19559712]

Ferrara C, Grau S, Jager C, Sondermann P, Brunker P, Waldhauer I, Hennig M, Ruf A, Rufer AC, Stihle M, Umana P, Benz J (2011) Unique carbohydrate-carbohydrate interactions are required for high affinity binding between $\mathrm{Fc}\{\gamma\}$ RIII and antibodies lacking core fucose. Proc Natl Acad Sci US A 108(31):12669-74. 1108455108 [pii] 10.1073/pnas.1108455108

Fitzsimmons CM, Falcone FH, Dunne DW (2014) Helminth allergens, parasite-specific IgE, and Its protective role in human immunity. Front Immunol 5:61 10.3389/fimmu.2014.00061 [PubMed: 24592267]

Frigeri LG, Zuberi RI, Liu FT (1993) Epsilon BP, a beta-galactoside-binding animal lectin, recognizes IgE receptor (Fc epsilon RI) and activates mast cells. Biochemistry 32(30):7644-7649 [PubMed: 8347574]

Gao P, Gibson PG, Baines KJ, Yang IA, Upham JW, Reynolds PN, Hodge S, James AL, Jenkins C, Peters MJ, Zhang J, Simpson JL (2015) Anti-inflammatory deficiencies in neutrophilic asthma: reduced galectin-3 and IL-1RA/IL-ip. RespirRes 16:5 10.1186/s12931-014-0163-5

Garman SC, Wurzburg BA, Tarchevskaya SS, Kinet JP, Jardetzky TS (2000) Structure of the Fc fragment of human IgE bound to its high-affinity receptor FceRIa. Nature 406(6793):259-266. 10.1038/35018500 [PubMed: 10917520]

Geha RS, Jabara HH, Brodeur SR (2003) The regulation of immunoglobulin E class-switch recombination. Nat Rev Immunol 3(9):721-732. 10.1038/nri1181 [PubMed: 12949496]

Gould HJ, Sutton BJ (2008) IgE in allergy and asthma today. Nat Rev Immunol 8(3):205-217. 10.1038/nri2273 [PubMed: 18301424]

Gould HJ, Sutton BJ, Beavil AJ, Beavil RL, McCloskey N, Coker HA, Fear D, Smurthwaite L (2003) The biology of IGE and the basis of allergic disease. Annu Rev Immunol 21:579-628. 10.1146/ annurev.immunol.21.120601.141103 [PubMed: 12500981]

Gurish MF, Austen KF (2012) Developmental origin and functional specialization of mast cell subsets. Immunity 37(1):25-33. 10.1016/j.immuni.2012.07.003 [PubMed: 22840841]

Harris MB, Chang CC, Berton MT, Danial NN, Zhang J, Kuehner D, Ye BH, Kvatyuk M, Pandolfi PP, Cattoretti G, Dalla-Favera R, Rothman PB (1999) Transcriptional repression of Stat6-dependent interleukin-4-induced genes by BCL-6: specific regulation of $i \epsilon$ transcription and immunoglobulin E switching. Mol Cell Bio 19:7264-7275 [PubMed: 10490661]

He JS, Meyer-Hermann M, Xiangying D, Zuan LY, Jones LA, Ramakrishna L, de Vries VC, Dolpady J, Aina H, Joseph S, Narayanan S, Subramaniam S, Puthia M, Wong G, Xiong H, Poidinger M, Urban JF, Lafaille JJ, Curotto de Lafaille MA (2013) The distinctive germinal center phase of IgE + B lymphocytes limits their contribution to the classical memory response. J Exp Med 210(12): 2755-2771. 10.1084/jem.20131539 [PubMed: 24218137]

He JS, Narayanan S, Subramaniam S, Ho WQ, Lafaille JJ, Curotto de Lafaille MA (2015) Biology of IgE production: IgE cell differentiation and the memory of $\mathrm{IgE}$ responses. Curr Top Microbiol Immunol 388:1-19. 10.1007/978-3-319-13725-4_1 [PubMed: 25553792]

He JS, Subramaniam S, Narang V, Srinivasan K, Saunders SP, Carbajo D, Wen-Shan T, Hidayah Hamadee N, Lum J, Lee A, Chen J, Poidinger M, Zolezzi F, Lafaille JJ, Curotto de Lafaille MA 
(2017) IgG1 memory B cells keep the memory of IgE responses. Nat Commun 8 (1):641 10.1038/ s41467-017-00723-0 [PubMed: 28935935]

Hebenstreit D, Wirnsberger G, Horejs-Hoeck J, Duschl A (2006) Signaling mechanisms, interaction partners, and target genes of STAT6. Cytokine Growth Factor Rev 17(3):173-188. 10.1016/ j.cytogfr.2006.01.004 [PubMed: 16540365]

Helm BA, Sayers I, Padlan EA, McKendrick JE, Spivey AC (1998) Structure/function studies on IgE as a basis for the development of rational IgE antagonists. Allergy 53(45 Suppl):77-82

Helm B, Marsh P, Vercelli D, Padlan E, Gould H, Geha R (1988) The mast cell binding site on human immunoglobulin E. Nature 331(6152):180-183. 10.1038/331180a0 [PubMed: 3123993]

Henault J, Riggs JM, Karnell JL, Liarski VM, Li J, Shirinian L, Xu L, Casey KA, Smith MA, Khatry DB, Izhak L, Clarke L, Herbst R, Ettinger R, Petri M, Clark MR, Mustelin T, Kolbeck R, Sanjuan MA (2016) Self-reactive IgE exacerbates interferon responses associated with autoimmunity. Nat Immunol 17(2):196-203. 10.1038/ni.3326 [PubMed: 26692173]

Henry AJ, McDonnell JM, Ghirlando R, Sutton BJ, Gould HJ (2000) Conformation of the isolated ce3 domain of IgE and its complex with the high-affinity receptor, FceRI. Biochemistry 39 (25):74067413 [PubMed: 10858288]

Holdom MD, Davies AM, Nettleship JE, Bagby SC, Dhaliwal B, Girardi E, Hunt J, Gould HJ, Beavil AJ, McDonnell JM, Owens RJ, Sutton BJ (2011) Conformational changes in IgE contribute to its uniquely slow dissociation rate from receptor FceRI. Nat Struct Mol Biol 18 (5):571-576. 10.1038/nsmb.2044 [PubMed: 21516097]

Holgate ST, Church MK (1982) Control of mediator release from mast cells. Clin Allergy 12 (Suppl): 5-13 [PubMed: 6183025]

Holland SM, DeLeo FR, Elloumi HZ, Hsu AP, Uzel G, Brodsky N, Freeman AF, Demidowich A, Davis J, Turner ML, Anderson VL, Darnell DN, Welch PA, Kuhns DB,/Frucht DM, Malech HL, Gallin JI, Kobayashi SD, Whitney AR, Voyich JM, Musser JM, Woellner C, Schaffer AA, Puck JM, Grimbacher B (2007) STAT3 mutations in the hyper-IgE syndrome. N Engl J Med 357(16): 1608-1619. 10.1056/NEJMoa073687 [PubMed: 17881745]

Hunt J, Beavil RL, Calvert RA, Gould HJ, Sutton BJ, Beavil AJ (2005) Disulfide linkage controls the affinity and stoichiometry of IgE FCe3-4 binding to FceRI. J Biol Chem 280(17):16808-16814. 10.1074/jbc.M500965200 [PubMed: 15743766]

Jabs F, Plum M, Laursen NS, Jensen RK, Molgaard B, Miehe M, Mandolesi M, Rauber MM, Pfutzner W, Jakob T, Mobs C, Andersen GR, Spillner E (2018) Trapping IgE in a closed conformation by mimicking CD23 binding prevents and disrupts FceRI interaction. Nat Commun 9(1):7 10.1038/ s41467-017-02312-7 [PubMed: 29295972]

Janeway CA, Travers P, Walport M, Shlomchik M (2001) Immunobiology In: The immune system in health and disease, 5 edn. Garland Publishing, New York

Jankovic D, Kullberg MC, Dombrowicz D, Barbieri S, Caspar P, Wynn TA, Paul WE, Cheever AW, Kinet JP, Sher A (1997) Fc epsilonRI-deficient mice infected with Schistosoma mansoni mount normal Th2-type responses while displaying enhanced liver pathology. J Immunol 159:1868-1875 [PubMed: 9257851]

Kaneko Y, Nimmeijahn F, Ravetch JV (2006) Anti-inflammatory activity of immunoglobulin G resulting from Fc sialylation. Science 313(5787):670-673 [PubMed: 16888140]

Kim B, Eggel A, Tarchevskaya SS, Vogel M, Prinz H, Jardetzky TS (2012) Accelerated disassembly of IgE-receptor complexes by a disruptive macromolecular inhibitor. Nature 491 (7425):613-617. 10.1038/nature11546 [PubMed: 23103871]

Kraft S, Kinet JP (2007) New developments in FceRI regulation, function and inhibition. Nat Rev Immunol 7(5):365-378. 10.1038/nri2072 [PubMed: 17438574]

Krapp S, Mimura Y, Jefferis R, Huber R, Sondermann P (2003) Structural analysis of human IgG-Fc glycoforms reveals a correlation between glycosylation and structural integrity. J Mol Biol 325(5): 979-989 [PubMed: 12527303]

Liu FT, Frigeri LG, Gritzmacher CA, Hsu DK, Robertson MW, Zuberi RI (1993) Expression and function of an IgE-binding animal lectin $(\epsilon B P)$ in mast cells. Immunopharmacology 26(3):187195 [PubMed: 8288440] 
Liu H, Archer NK, Dillen CA, Wang Y, Ashbaugh AG, Ortines RV, Lee SK, Kao T, Miller LS (2017) Keratinocyte-specific deletion of STAT3 promotes elevated serum IgE in response to Staphylococcus aureus exposure: relevance to hyper-IgE syndrome. J Immunol 198:194-208

Mandler R, Finkelman FD, Levine AD, Snapper CM (1993) IL-4 induction of IgE class switching by lipopolysaccharide-activated murine B cells occurs predominantly through sequential switching. J Immunol 150:407-418 [PubMed: 8419474]

Marichal T, Starkl P, Reber LL, Kalesnikoff J, Oettgen HC, Tsai M, Metz M, Galli SJ (2013) A beneficial role for immunoglobulin $\mathrm{E}$ in host defense against honeybee venom. Immunity 39 (5): 963-975. 10.1016/j.immuni.2013.10.005 [PubMed: 24210352]

Matsumoto A, Shikata K, Takeuchi F, Kojima N, Mizuochi T (2000) Autoantibody activity of IgG rheumatoid factor increases with decreasing levels of galactosylation and sialylation. J Biochem 128(4):621-628 [PubMed: 11011144]

McCloskey N, Hunt J, Beavil RL, Jutton MR, Grundy GJ, Girardi E, Fabiane SM, Fear DJ, Conrad DH, Sutton BJ, Gould HJ (2007) Soluble CD23 monomers inhibit and oligomers stimulate IGE synthesis in human B cells. J Biol Chem 282(33):24083-24091. 10.1074/jbc.M703195200 [PubMed: 17576766]

Metz M, Piliponsky AM, Chen CC, Lammel V, Abrink M, Pejler G, Tsai M, Galli SJ (2006) Mast cells can enhance resistance to snake and honeybee venoms. Science 313(5786):526-530. 10.1126/ science.1128877 [PubMed: 16873664]

Milner JD, Brenchley JM, Laurence A, Freeman AF, Hill BJ, Elias KM, Kanno Y, Spalding C, Elloumi HZ, Paulson ML, Davis J, Hsu A, Asher AI, O’Shea J, Holland SM, Paul WE, Douek DC (2008) Impaired $\mathrm{T}(\mathrm{H}) 17$ cell differentiation in subjects with autosomal dominant hyper-IgE syndrome. Nature 452(7188):773-776. 10.1038/nature06764 [PubMed: 18337720]

Misaghi S, Senger K, Sai T, Qu Y, Sun Y, Hamidzadeh K, Nguyen A, Jin Z, Zhou M, Yan D, Lin WY, Lin Z, Lorenzo MN, Sebrell A, Ding J, Xu M, Caplazi P, Austin CD, Balazs M, Roose-Girma M, DeForge L, Warming S, Lee WP, Dixit VM, Zarrin AA (2013) Polyclonal hyper-IgE mouse model reveals mechanistic insights into antibody class switch recombination. Proc Natl Acad Sci U S A 110(39):15770-15775. 10.1073/pnas.1221661110 [PubMed: 24019479]

Miyawaki S, Ritchie RF (1973) Nucleolar antigen specfic for antinucleolar antibody in the sera of patients with rheumatologic disease. Arthritis Rheum 16:726-736 [PubMed: 4585926]

Mogensen TH (2016) Primary immunodeficiencies with elevated IgE. Int Rev Immunol 35(1):39-56. 10.3109/08830185.2015.1027820 [PubMed: 25970001]

Mukai K, Tsai M, Starkl P, Marichal T, Galli SJ (2016) IgE and mast cells in host defense against parasites and venoms. Semin Immunopathol 38(5):581-603. 10.1007/s00281-016-0565-1 [PubMed: 27225312]

Nettleton MY, Kochan JP (1995) Role of glycosylation sites in the IgE Fc molecule. Int Arch Allergy Immunol 107(1-3):328-329 [PubMed: 7613162]

Nieminen P, Morgan NV, Fenwick AL, Parmanen S, Veistinen L, Mikkola ML, van der Spek PJ, Giraud A, Judd L, Arte S, Brueton LA, Wall SA, Mathijssen IM, Maher ER, Wilkie AO, Kreiborg S, Thesleff I (2011) Inactivation of IL11 signaling causes craniosynostosis, delayed tooth eruption, and supernumerary teeth. Am J Hum Genet 89(1):67-81. 10.1016/j.ajhg.2011.05.024 [PubMed: 21741611]

Niki T, Tsutsui S, Hirose S, Aradono S, Sugimoto Y, Takeshita K, Nishi N, Hirashima M (2009) Galectin-9 is a high affinity IgE-binding lectin with anti-allergic effect by blocking IgE-antigen complex formation. J Biol Chem 284(47):32344-32352. 10.1074/jbc.M109.035196 [PubMed: 19776007]

Pagan JD, Kitaoka M, Anthony RM (2018) Engineered sialylation of pathogenic antibodies in vivo attenuates autoimmune disease. Cell. 10.1016/jxell.2017.11.041

Palaniyandi S, Tomei E, Li Z, Conrad DH, Zhu X (2011) CD23-dependent transcytosis of IgE and immune complex across the polarized human respiratory epithelial cells. J Immunol 186 (6):34843496. 10.4049/jimmunol.1002146 [PubMed: 21307287]

Palm NW, Rosenstein RK, Yu S, Schenten DD, Florsheim E, Medzhitov R (2013) Bee venom phospholipase A2 induces a primary type 2 response that is dependent on the receptor ST2 and 
confers protective immunity. Immunity 39(5):976-985. 10.1016/j.immuni.2013.10.006 [PubMed: 24210353]

Pawankar R, Canonica GW, Holgate S, Lockey RF (2011). WAO white book on allergy 2011-2012: executive summary

Pincetic A, Bournazos S, DiLillo DJ, Maamary J, Wang TT, Dahan R, Fiebiger BM, Ravetch JV (2014) Type I and type II Fc receptors regulate innate and adaptive immunity. Nat Immunol 15 (8): 707-716. 10.1038/ni.2939 [PubMed: 25045879]

Plomp R, Hensbergen PJ, Rombouts Y, Zauner G, Dragan I, Koeleman CA, Deelder AM, Wuhrer M (2013) Site-specific N-glycosylation analysis of human immunoglobulin E. J Proteome Res. $10.1021 / \mathrm{pr} 400714 \mathrm{w}$

Reinhardt RL, Liang HE, Locksley RM (2009) Cytokine-secreting follicular T cells shape the antibody repertoire. Nat Immunol 10(4):385-393. 10.1038/ni.1715 [PubMed: 19252490]

Riccio AM, Mauri P, De Ferrari L, Rossi R, Di Silvestre D, Benazzi L, Chiappori A, Dal Negro RW, Micheletto C, Canonica GW (2017) Galectin-3: an early predictive biomarker of modulation of airway remodeling in patients with severe asthma treated with omalizumab for 36 months. Clin Transl Allergy 7:6 10.1186/s13601-017-0143-1 [PubMed: 28293414]

Rieber EP, Rank G, Kohler I, Krauss S (1993) Membrane expression of Fc $\epsilon$ RII/CD23 and release of soluble CD23 by follicular dendritic cells. Adv Exp Med Biol 329:393-398 [PubMed: 8379401]

Ronnblom L, Alm GV (2001) A pivotal role for the natural interferon a-producing cells (plasmacytoid dendritic cells) in the pathogenesis of lupus. J Exp Med 194:F59-F63 [PubMed: 11748288]

Sayers I, Cain SA, Swan JR, Pickett MA, Watt PJ, Holgate ST, Padlan EA, Schuck P, Helm BA (1998) Amino acid residues that influence FceRI-mediated effector functions of human immunoglobulin E. Biochemistry 37(46):16152-16164. 10.1021/bi981456k [PubMed: 9819207]

Scherer HU, van der Woude D, Ioan-Facsinay A, el Bannoudi H, Trouw LA, Wang J, Haupl T, Burmester GR, Deelder AM, Huizinga TW, Wuhrer M, Toes RE (2010) Glycan profiling of anticitrullinated protein antibodies isolated from human serum and synovial fluid. Arthritis Rheum 62(6):1620-1629. 10.1002/art.27414 [PubMed: 20178128]

Shade KT, Platzer B, Washburn N, Mani V, Bartsch YC, Conroy M, Pagan JD, Bosques C, Mempel TR, Fiebiger E, Anthony RM (2015) A single glycan on IgE is indispensable for initiation of anaphylaxis. J Exp Med 212(4):457-467. 10.1084/jem.20142182 [PubMed: 25824821]

Shields RL, Lai J, Keck R, O’Connell LY, Hong K, Meng YG, Weikert SH, Presta LG (2002) Lack of fucose on human IgG1N-linked oligosaccharide improves binding to human Fc $\gamma$ RIII and antibody-dependent cellular toxicity. J Biol Chem 277(30):26733-26740 [PubMed: 11986321]

Siegel AM, Heimall J, Freeman AF, Hsu AP, Brittain E, Brenchley JM, Douek DC, Fahle GH, Cohen JI, Holland SM, Milner JD (2011) A critical role for STAT3 transcription factor signaling in the development and maintenance of human T cell memory. Immunity 35(5):806-818. 10.1016/ j.immuni.2011.09.016 [PubMed: 22118528]

Sondermann P, Huber R, Oosthuizen V, Jacob U (2000) The 3.2-a crystal structure of the human IgG1 Fc fragment-Fc $\gamma$ RIII complex. Nature 406(6793):267-273. 10.1038/35018508 [PubMed: 10917521]

Sondermann P, Pincetic A, Maamary J, Lammens K, Ravetch JV (2013) General mechanism for modulating immunoglobulin effector function. Proc Natl Acad Sci USA. 10.1073/pnas. 1307864110

Sowerwine KJ, Holland SM, Freeman AF (2012) Hyper-IgE syndrome update. Ann N Y Acad Sci 1250:25-32. 10.1111/j.1749-6632.2011.06387.x [PubMed: 22268731]

van de Geijn FE, Wuhrer M, Selman MH, Willemsen SP, de Man YA, Deelder AM, Hazes JM, Dolhain RJ (2009) Immunoglobulin G galactosylation and sialylation are associated with pregnancy-induced improvement of rheumatoid arthritis and the postpartum flare: results from a large prospective cohort study. Arthritis Res Ther 11(6):R193 ar2892 [pii] 10.1186/ar2892 [PubMed: 20015375]

Vercelli D, Helm B, Marsh P, Padlan E, Geha RS, Gould H (1989) The B-cell binding site on human immunoglobulin E. Nature 338(6217):649-651. 10.1038/338649a0 [PubMed: 2468089]

Vieira P, Rajewsky K (1988) The half-lives of serum immunoglobulins in adult mice. Eur J Immunol 18(2):313-316. 10.1002/eji.1830180221 [PubMed: 3350037] 
Wan T, Beavil RL, Fabiane SM, Beavil AJ, Sohi MK, Keown M, Young RJ, Henry AJ, Owens RJ, Gould HJ, Sutton BJ (2002) The crystal structure of IgE Fc reveals an asymmetrically bent conformation. Nat Immunol 3(7):681-686. 10.1038/ni811 [PubMed: 12068291]

Wesemann DR, Magee JM, Boboila C, Calado DP, Gallagher MP, Portuguese AJ, Manis JP, Zhou X, Recher $M^{\wedge}$ Rajewsky K, Notarangelo LD, Alt FW (2011) Immature B cells preferentially switch to IgE with increased direct Sp to Se recombination. J Exp Med 208 (13):2733-2746. 10.1084/jem. 20111155 [PubMed: 22143888]

Wesemann DR, Portuguese AJ, Magee JM, Gallagher MP, Zhou X, Panchakshari RA, Alt FW (2012) Reprogramming IgH isotype-switched B cells to functional-grade induced pluripotent stem cells. Proc Natl Acad Sci USA 109(34):13745-13750. 10.1073/pnas.1210286109 [PubMed: 22869756]

Wu G, Hitchen PG, Panico M, North SJ, Barbouche MR, Binet D, Morris HR, Dell A, Haslam SM (2016) Glycoproteomic studies of IgE from a novel hyper IgE syndrome linked to PGM3 mutation. Glycoconj J 33(3):447-456. 10.1007/s10719-015-9638-y [PubMed: 26687240]

Wuhrer M, Stam JC, van de Geijn FE, Koeleman CA, Verrips CT, Dolhain RJ, Hokke CH, Deelder AM (2007) Glycosylation profiling of immunoglobulin $\mathrm{G}(\mathrm{IgG})$ subclasses from human serum. Proteomics 7(22):4070-4081. 10.1002/pmic.200700289 [PubMed: 17994628]

Wurzburg BA, Garman SC, Jardetzky TS (2000) Structure of the human IgE-Fc C epsilon 3-C epsilon 4 reveals conformational flexibility in the antibody effector domains. Immunity 13 (3):375-385 [PubMed: 11021535]

Xiao H, Woods EC, Vukojicic P, Bertozzi CR (2016) Precision glycocalyx editing as a strategy for cancer immunotherapy. Proc Natl Acad Sci USA 113(37):10304-10309. 10.1073/pnas. 1608069113 [PubMed: 27551071]

Yang Z, Sullivan BM, Allen CD (2012) Fluorescent in vivo detection reveals that $\operatorname{IgE}(+)$ B cells are restrained by an intrinsic cell fate predisposition. Immunity 36(5):857-872. 10.1016/j.immuni. 2012.02.009 [PubMed: 22406270]

Young RJ, Owens RJ, Mackay GA, Chan CM, Shi J, Hide M, Francis DM, Henry AJ, Sutton BJ, Gould HJ (1995) Secretion of recombinant human IgE-Fc by mammalian cells and biological activity of glycosylation site mutants. Protein Eng 8(2):193-199 [PubMed: 7543206]

Yu LC, Montagnac G, Yang PC, Conrad DH, Benmerah A, Perdue MH (2003) Intestinal epithelial CD23 mediates enhanced antigen transport in allergy: evidence for novel splice forms. Am J Physiol Gastrointest Liver Physiol 285(1):G223-G234. 10.1152/ajpgi.00445.2002 [PubMed: 12637252]

Zuberi RI, Frigeri LG, Liu FT (1994) Activation of rat basophilic leukemia cells by $\epsilon$ BP, an IgEbinding endogenous lectin. Cell Immunol 156(1):1-12 [PubMed: 8200029] 


\section{(a)}

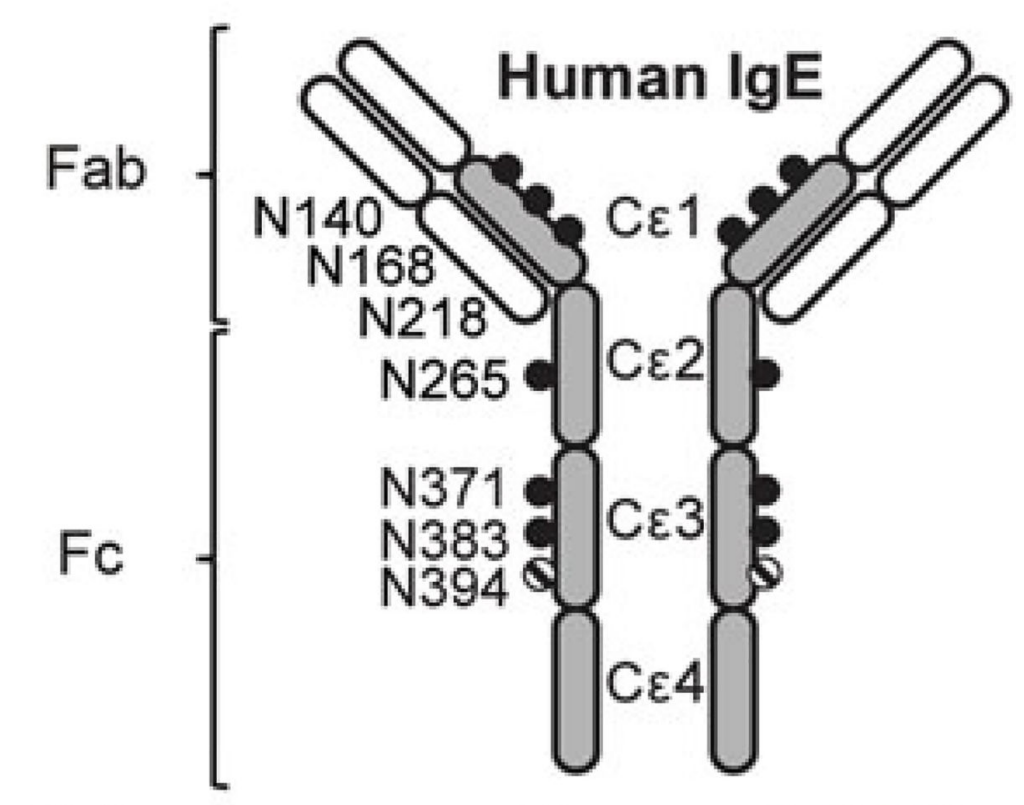

\section{(b) Complex}

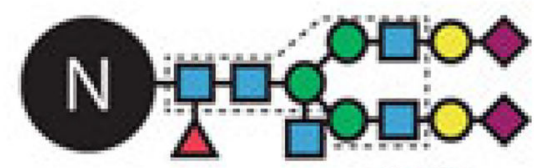
Oligo
mannose

Fig. 1. Human IgE and its glycans.

a Schematics of IgE structure and glycosylation. Predicted N-glycosylation sites in each constant domain $(\mathrm{C} \varepsilon$ ) are represented by closed and open circles for complex and oligomannose glycans, respectively. b Complex glycans are composed of fucose (red), GlcNAc (blue), mannose (green), galactose (yellow circles), and sialic acid (pink). Core complex structure is shown in dotted box. Oligomannose glycans are composed of GlcNAc and between 5 and 9 mannoses 